\title{
Response of NPK on Growth and Yield of Potato (Solanum tuberosum L.) under Calcareous Soils of Bihar
}

\author{
Pankaj Kumar, D. K. Dwivedi, V. Bharati*, Aman Tigga, \\ H. Singh and Anshuman Dwivedi
}

\author{
Dr. Rajendra Prasad Central Agricultural University, Pusa, Samastipur, Bihar, India
}

*Corresponding author

\section{A B S T R A C T}

\begin{tabular}{|l|}
\hline Ke y w or d s \\
NPK, Potato, 150\% \\
RDF, Tuber yield, \\
Nutrient uptake, \\
Calcareous soil
\end{tabular}

\section{Keywords}

NPK, Potato, $150 \%$ RDF, Tuber yield, Nutrient uptake, Article Info

\section{Accepted:}

10 February 2021
An experiment was conducted in the year 2016-2017 and 2017-2018 on potato with potato variety Kufri Arun with seven treatments viz., T1- 50\% RDF of NPK, T2- 100\% RDF of NPK, T3- $150 \%$ RDF of NPK, T4- 100\% RDF of PK, T5- 100\% RDF of NK, T6- $100 \%$ RDF of NP and $\mathrm{T}_{7^{-}}$Absolute control (without NPK) were laid out in Randomized Block Design with four replications at Tirhut College of Agriculture, Dholi, Muzaffarpur, Bihar during rabi season of both the year. The soil of experimental plot was entisol, sandy loam in texture and low in available $\mathrm{N}, \mathrm{P}_{2} \mathrm{O}_{5}$ and $\mathrm{K}_{2} \mathrm{O}$ with a $\mathrm{pH}$ of 8.30 . It has semi-arid, sub-tropical climate, which is greatly influenced by south-west monsoon with an average annual rainfall of $1270 \mathrm{~mm}$. All the growth parameters like percent plant emergence, plant height, dry matter accumulation and bulking rate were significantly influenced by the different rate of NPK application. Among all treatment, T3- $150 \%$ of NPK application proved to be significantly superior in all growth character, yield attributing parameters, yield of potato tubers, NPK content in plants, nutrient uptake by crop, available $\mathrm{N}, \mathrm{P}_{2} \mathrm{O}_{5}$ and $\mathrm{K}_{2} \mathrm{O}$ in soil, economics, fertilizer use efficiency, except agronomic efficiency and production use efficiency during the experimentation. Skipping of any one major nutrient resulted in poor growth and yield of crop.. Thus, the increment in potato tuber yield was noticed by increasing levels of nitrogen, phosphorus and potassium. Also the marketable yield, vine yield, tuber: vine ratio and harvest index was recorded highest in treatment $\mathrm{T}_{3}-150 \%$ of RDF of NPK. This treatment also recorded significantly higher NPK content and uptake of nutrients and fertilizer use efficiency. Agronomic use efficiency for NPK was registered significantly higher with treatment $\mathrm{T}_{2^{-}} 100 \% \mathrm{RDF}\left(150: 90: 100 \mathrm{~kg} \mathrm{~N}: \mathrm{P}_{2} \mathrm{O}_{5}: \mathrm{K}_{2} \mathrm{O}\right.$ $\mathrm{kg} / \mathrm{ha}$ ). Production use efficiency for nitrogen, phosphorus and potassium was observed in treatment $\mathrm{T}_{4^{-}} 100 \%$ RDF of PK, $\mathrm{T}_{5^{-}} 100 \%$ RDF of NK and $100 \%$ of NP. Available nitrogen, phosphorus and potassium of post-harvest soil of potato crop also influenced by the different levels of nutrient application and maximum found with the application of $150 \%$ RDF of NPK. Thus, application of $225 \mathrm{~kg} \mathrm{~N}, 135 \mathrm{~kg} \mathrm{P}_{2} \mathrm{O}_{5}$ and $150 \mathrm{~kg} \mathrm{~K} \mathrm{~K}_{2} \mathrm{O} \mathrm{kg} / \mathrm{ha}$ may be adopted for potato cultivation under calcareous soil of North Bihar.

\section{Introduction}

Potato (Solanum tuberosum L.) is an important staple food of the world and it is world's fourth important food crop after rice, wheat and maize. Potato is most important cultivated food crop and is believed to contribute significantly to sustain future 
global food security. The production potential of cereal is limited and it can be increased only upto a certain level by involving complex technology with intensive energy use and high expenditure. Thus option lies in the production of alternate food crops like root and tuber crops. Potato yield potential is many fold higher in comparison to any crops grown during rabi season. Balanced fertilization has proved to be a kingpin in agricultural production under different farming situations and contributed to nearby $50 \%$ increase in agriculture production (Singh et al., 2007). Potato production depends on many factors. Among them, judicious application of nitrogen, phosphorus and potassium play a vital role. A mature crop of potato yielding 25-30 t/ha removes $110 \mathrm{~kg}$ $\mathrm{N} / \mathrm{ha}, 50 \mathrm{~kg} \mathrm{P}_{2} \mathrm{O}_{5}$ and $225 \mathrm{~kg} \mathrm{~K}_{2} \mathrm{O} / \mathrm{ha}$, thus potato removes large amount of potassium $\left(\mathrm{K}_{2} \mathrm{O}\right)$ followed by nitrogen and relatively low amount of phosphate (Choudhary, 1990). The potato as well as all crops need adequate amount of nutrient for sustaining the optimum yield potential. If nutrient is not applied in balanced manner thus result in decrease the yield. Keeping the above facts in view, the present investigation was carried out to study the Response of NPK on growth and yield of potato (Solanum tuberosum L.).

\section{Materials and Methods}

The present investigation entitled "Response of NPK on growth and yield of potato" was carried out during rabi season of 2016 and 2017 at the research farm of Tirhut College of Agriculture, Dholi, Muzaffarpur (Dr. Rajendra Prasad Central Agricultural University, Pusa, Samastipur, Bihar). The soil of the experimental plot was calcareous in nature, the free calcium carbonate ranging from 10 to $45 \%$ which is distributed throughout the depth of the profile. The soil of experimental field was Entisol and sandy loam in texture. Soil was alkaline in reaction
(pH- 8.30), low in organic carbon $(0.49 \%)$, available $\mathrm{N}(238 \mathrm{~kg} / \mathrm{ha})$, available $\mathrm{P}_{2} \mathrm{O}_{5}$ (19.68 kg/ha) and available $\mathrm{K}_{2} \mathrm{O}$ (119.21 $\mathrm{kg} / \mathrm{ha})$. Seven treatments on NPK levels were taken out for study purpose on the growth and yield of potato. These were $\mathrm{T}_{1^{-}} \quad 50 \%$ recommended dose of fertilizer (RDF) of NPK, $T_{2}-100 \%$ RDF of NPK, $T_{3^{-}} 150 \%$ RDF of NPK, $\mathrm{T}_{4}-\mathrm{RDF}$ of PK (without N), $\mathrm{T}_{5^{-}} \mathrm{RDF}$ of NK (without $\mathrm{P}$ ), $\mathrm{T}_{6}-\mathrm{RDF}$ of NP (without $\mathrm{K}$ ) and $\mathrm{T}_{7^{-}}$absolute control (without NPK). Recommended dose of fertilizer was $150 \mathrm{~kg}$ $\mathrm{N}, 90 \mathrm{~kg} / \mathrm{ha} \mathrm{P}_{2} \mathrm{O}_{5}, 100 \mathrm{~kg} / \mathrm{ha} \mathrm{K}_{2} \mathrm{O}$ for potato crop. The treatments were applied in randomised block design with four replications. The potato cultivar Kufri Arun was taken under test which has red skin colour with medium duration of 110 days. Nitrogen, phosphorus and potassium were applied in form of Urea, Di-ammonium Phosphate and Muriate of Potash, respectively. Whereas under the treatment PK (without nitrogen), the phosphate was applied through single super phosphate. Half of the nitrogen and full PK was applied at the time of planting. The remaining nitrogen was applied after first irrigation at the time of weeding followed by earthing up of the potato crop. All recommended agronomic practices as well as plant protection measures were adopted for the potato crop production. All growth attributing characters and yield parameters were observed from five randomly selected and tagged plants of each plot. These five plants of each treatment were remained continued upto harvesting without dehaulming. By the five sampled plants, the data of vine yield and dry matter yield was also essentially recorded at the time of harvest for the purpose of research work. The whole plots of each treatment were dehaulmed 10 days before the final harvesting of the experimentation. The F-test was computed to find out the significance of treatments impact on the potato crop. Standard errors of variance and critical differences of various 
treatments were computed out at 5\% level of significance to assess the authenticity of each respective treatment.

\section{Results and Discussion}

The various levels of NPK showed different effect on crop growth, yield attributing characters and yield of the potato crop. Effect of NPK on growth, yield attributes and yield observed at 45, 60, 75 days after sowing and at harvest but here the data related to various aspects at the time of 75 DAP and at harvest has been presented (Table 1) and discussed.

Percent emergence of potato crop at 30 days after planting (DAP) ranged from 95.31 to 96.80 and showed non-significant difference among different treatments. Singh and Lal (2012) reported that the emergence of seed tubers in potato ranged from 90 to $98 \%$, however, there was no effect of fertilizer treatments on the emergence of seed tubers. Among the various treatments, treatment $\mathrm{T}_{3^{-}}$ $150 \%$ NPK (225:135:150 kg/ha) recorded significantly higher plant height $(48.47 \mathrm{~cm})$, number of shoots/hill (5.88), number of leaves per plant (59.25) at the time of 75 DAP followed by $\mathrm{T}_{2}-100 \% \mathrm{RDF}$ while $\mathrm{T}_{7}$ (absolute control without NPK) and other treatments gave lower response. Skipping of any nutrients (NP, PK and NK) did not created any significant impact on plant height, number of shoots per hill and number of leaves per plant. Kumar et al., (2004) also reported that the application of $150 \%$ of RDF increased the number of shoots per plant. Number of leaves per plant is influenced positively due to increasing level of nitrogen (Pandey et al., 2007).

Dry matter accumulation was recorded significantly higher with the application of $150 \%$ RDF of NPK at all the growth stages. Patel (2013) also obtained higher dry matter per plant under the treatment of $150 \%$ RDF in potato. Likewise the tuber yield per plant was significantly higher with the application of the same treatment (150\% RDF of NPK). The tuber yield (g/plant) produced more with the age of crop. Further, nitrogen boosts the tuber initiation by more photosynthesis activity and yield on optimum limit beyond which it delays tuber development and increase foliage growth at the expense of tuberisation (Sharma and Kumar 2014).

The findings revealed significant variations in marketable yield among different treatments. The present study showed that the highest marketable potato tuber yield $(276.60 \mathrm{q} / \mathrm{ha})$ was obtained with the treatment $\mathrm{T}_{3^{-}} 150 \%$ RDF of NPK fertilizer followed by $\mathrm{T}_{2}-100 \%$ RDF of NPK fertilizers (231.70 q/ha) and minimum marketable yield was noted in treatment $\mathrm{T}_{7^{-}}$absolute control. Treatment $\mathrm{T}_{3^{-}}$ $150 \%$ RDF of NPK was statistically superior over rest of treatments. The increase in marketable tuber yield was due to the increase in levels of $\mathrm{N}, \mathrm{P}$ and $\mathrm{K}$ at each successive levels. The nitrogen applied at higher levels was found to be beneficial. This might be due to the accumulation of adequate quantity of photosynthate transfer from source to sink. This finding is in confirmation with those of Kumar et al., 2008).

Skipping of any major nutrients resulted in a poor all growth parameters, yield attributing characters and ultimately the yield.

Uptake of nutrients depends upon available nutrient status of soil, plants vegetative as well as reproductive health, metabolic activity of crop and fertilizer used etc. Data obtained for uptake of $\mathrm{N}, \mathrm{P}$ and $\mathrm{K}$ by tuber, vine and total uptake had significant effect and differences to different treatments. Maximum uptake of $\mathrm{N}, \mathrm{P}$ and $\mathrm{K}$ was obtained under treatment, $\mathrm{T}_{3}-150 \%$ RDF of NPK, which was statistically superior over rest of treatments. 
Table.1 Effect of NPK levels on the growth and yield of potato (Pooled data 2016-17 \&2017-18)

\begin{tabular}{|c|c|c|c|c|c|c|c|c|c|c|c|}
\hline Treatments & $\begin{array}{l}\text { Germination } \\
(\%)\end{array}$ & $\begin{array}{c}\text { Plant } \\
\text { height } \\
(\mathrm{cm})\end{array}$ & $\begin{array}{l}\text { Number of } \\
\text { shoots/hill }\end{array}$ & $\begin{array}{c}\text { Number of } \\
\text { leaves/ } \\
\text { plant }\end{array}$ & $\begin{array}{l}\text { Dry matter } \\
\text { accumulatio } \\
\text { n (g/plant) }\end{array}$ & $\begin{array}{l}\text { Tuber } \\
\text { yield per } \\
\text { plant (g) }\end{array}$ & $\begin{array}{c}\text { Marketable } \\
\text { tuber yield } \\
\text { (q/ha) }\end{array}$ & B:C ratio & $\begin{array}{c}\text { Total } \\
\text { N-uptake } \\
\text { (kg/ha) }\end{array}$ & $\begin{array}{l}\text { Total P - } \\
\text { uptake } \\
\text { (kg/ha) }\end{array}$ & $\begin{array}{l}\text { Total K } \\
\text { uptake } \\
\text { (kg/ha) }\end{array}$ \\
\hline$T_{1}$ & 96.04 & 34.32 & 3.96 & 41.25 & 53.60 & 176.11 & 151.00 & 0.55 & 47.68 & 13.44 & 59.08 \\
\hline $\mathbf{T}_{2}$ & 96.60 & 42.60 & 4.96 & 48.50 & 61.86 & 267.44 & 231.70 & 1.32 & 90.12 & 20.77 & 100.25 \\
\hline $\mathbf{T}_{3}$ & 96.80 & 48.47 & 5.88 & 59.25 & 70.80 & 317.14 & 276.60 & 1.61 & 130.51 & 27.52 & 158.87 \\
\hline $\mathbf{T}_{4}$ & 95.90 & 34.31 & 4.03 & 39.50 & 46.89 & 169.13 & 151.80 & 0.39 & 35.06 & 14.09 & 62.50 \\
\hline $\mathbf{T}_{5}$ & 95.70 & 40.84 & 3.59 & 46.75 & 60.37 & 204.01 & 194.10 & 1.07 & 74.40 & 14.31 & 82.85 \\
\hline$T_{6}$ & 96.04 & 40.21 & 4.61 & 45.75 & 59.03 & 181.97 & 170.60 & 0.67 & 63.00 & 15.77 & 52.38 \\
\hline $\mathbf{T}_{7}$ & 95.31 & 30.50 & 3.68 & 37.25 & 45.61 & 150.51 & 129.80 & 0.40 & 32.00 & 10.07 & 42.11 \\
\hline SEm \pm & 1.44 & 1.53 & 0.33 & 0.90 & 2.44 & 7.14 & 9.70 & 0.043 & 5.21 & 137 & 5.58 \\
\hline \multirow[t]{2}{*}{$\mathrm{CD}(\mathrm{P}=0.05)$} & NS & 3.93 & 0.77 & 2.72 & 7.33 & 21.42 & 23.70 & 0.13 & 15.62 & 3.21 & 16.64 \\
\hline & \multicolumn{11}{|c|}{$\begin{array}{c}\text { Treatments: T1- } 50 \% \text { RDF of NPK; T2- } 100 \% \text { of RDF of NPK; T3- } 150 \% \text { RDF of NPK; T4-100\% RDF of PK; T5- 100\% of NK; T6- } 100 \% \text { RDF of } \\
\text { NP; T7- Absolute control }\end{array}$} \\
\hline
\end{tabular}

Table.2 Effect of NPK levels on the available NPK in soil and nutrient use efficiency of potato crop. (Pooled data 2016-17 \&2017-18)

\begin{tabular}{|c|c|c|c|c|c|c|c|c|c|c|c|c|}
\hline \multirow[t]{2}{*}{ Treatments } & \multirow{2}{*}{$\begin{array}{l}\text { Available } \\
\mathrm{N} \text { in soil } \\
\text { (kg/ha) }\end{array}$} & \multirow{2}{*}{$\begin{array}{c}\text { Available } \\
\mathrm{P}_{2} \mathrm{O}_{5} \text { in } \\
\text { soil } \\
(\mathrm{kg} / \mathrm{ha})\end{array}$} & \multirow{2}{*}{$\begin{array}{l}\text { Available } \\
\mathrm{K}_{2} \mathrm{O} \text { in } \\
\text { soil } \\
(\mathrm{kg} / \mathrm{ha})\end{array}$} & \multicolumn{3}{|c|}{$\begin{array}{c}\text { Fertilizer use efficiency } \\
\qquad(\%)\end{array}$} & \multicolumn{3}{|c|}{ Agronomic efficiency (\%) } & \multicolumn{3}{|c|}{ Production efficiency $(\%)$} \\
\hline & & & & $\mathbf{N}$ & $\mathrm{P}$ & K & $\mathrm{N}$ & $\mathrm{P}$ & $\mathrm{K}$ & $\mathrm{N}$ & $\mathrm{P}$ & $\mathrm{K}$ \\
\hline T1 & 184.78 & 22.73 & 127.35 & 20.92 & 7.50 & 33.94 & 29.72 & 49.54 & 44.58 & 298.90 & 1060.34 & 241.21 \\
\hline $\mathbf{T} 2$ & 198.23 & 23.68 & 120.25 & 38.75 & 11.89 & 58.14 & 68.87 & 114.78 & 103.30 & 248.02 & 1018.78 & 222.96 \\
\hline T3 & 217.33 & 26.12 & 134.63 & 43.78 & 12.92 & 77.84 & 63.69 & 106.16 & 95.54 & 201.92 & 957.59 & 165.87 \\
\hline $\mathbf{T 4}$ & 168.38 & 24.32 & 130.42 & - & 4.47 & 20.39 & - & 13.65 & 12.28 & 377.86 & 961.53 & 212.00 \\
\hline T5 & 207.42 & 19.65 & 131.82 & 28.27 & - & 40.74 & 42.14 & - & 63.20 & 246.53 & 1281.40 & 221.40 \\
\hline T6 & 205.90 & 23.50 & 108.28 & 20.60 & 6.33 & - & 21.45 & 35.76 & - & 241.94 & 966.40 & 290.95 \\
\hline T7 & 165.23 & 14.53 & 101.74 & - & - & - & - & - & - & 375.80 & 1193.84 & 285.50 \\
\hline SEm \pm & 5.54 & 0.67 & 3.95 & 2.17 & 0.47 & 4.56 & 1.52 & 2.05 & 1.76 & 5.11 & 14.97 & 4.30 \\
\hline $\mathrm{CD}(\mathrm{P}=\mathbf{0 . 0 5})$ & 16.63 & 2.02 & 11.85 & 6.53 & 1.43 & 13.86 & 4.58 & 6.15 & 5.29 & 15.34 & 45.28 & 12.87 \\
\hline
\end{tabular}


Higher nutrient content at higher level of fertilizer application together with higher dry matter production resulted in higher nutrient uptake by the potato crop. Similar results were reported by Patel (2013) who also recorded higher nutrient uptake (NPK) under the treatment of $150 \%$ RDF to potato crop. Thus the experimental result revealed that application of $150 \% \mathrm{RDF}$ of NPK (Kg/ha) i.e. 225:135:150 kg N: $\mathrm{P}_{2} \mathrm{O}_{5}: \mathrm{K}_{2} \mathrm{O} \mathrm{kg} / \mathrm{ha}$ was found suitable for optimum production of potato Kufri Arun a medium duration variety.

Fertilizer use efficiency of N,P and K were significantly influenced by increasing level of $\mathrm{N}, \mathrm{P}$ and $\mathrm{K}$. Maximum fertilizer use efficiency $(47.78 \%)$ was obtained under treatment $\mathrm{T}_{3}-150 \%$ RDF of NPK which was statistically superior over rest of treatments. Agronomic efficiency of $\mathrm{N}, \mathrm{P}$ and $\mathrm{K}$ were significantly influenced by increasing level of $\mathrm{N}, \mathrm{P}$ and $\mathrm{K}$. Maximum agronomic use efficiency was obtained under $\mathrm{T}_{2}-100 \% \mathrm{RDF}$ of NPK which was statistically superior over rest of treatments. Production efficiency of N, $\mathrm{P}$ and $\mathrm{K}$ were recorded significantly higher under treatment $\mathrm{T}_{4^{-}} 100 \% \mathrm{RDF}$ of $\mathrm{PK}, \mathrm{T}_{5^{-}}$ $100 \%$ RDF of NK and $\mathrm{T}_{6^{-}} 100 \%$ RDF of NP, while minimum production efficiency was noticed under treatment $\mathrm{T}_{3^{-}} 150 \%$ RDF of NPK. It might be due to difference in their impact with per unit increase of nutrient applied (Table 2). Similar results were reported by Kumar et al., (2008) and Singh and Lal (2012).

Application of $\mathrm{T}_{3^{-}} 150 \%$ RDF of NPK recorded maximum available $\mathrm{N}, \mathrm{P}_{2} \mathrm{O}_{5}$ and $\mathrm{K}_{2} \mathrm{O}$ in soil which was significantly superior over other treatments. It might be due to application of higher dose of fertilizer which get stored in soil even after adequate supply of nutrient for plant growth and yield of potato and it was also influenced by the uptake of nutrients.
The perusal of data, it was indicated that increasing $\mathrm{N}, \mathrm{P}$ and $\mathrm{K}$ levels significantly affect the production and benefit: cost ratio and this was significantly optimum with the treatment $\mathrm{T}_{3^{-}} 150 \% \mathrm{RDF}$ of NPK (1.61) which was significantly higher than others (Table 1). Kumar et al., (2008) and Singh and Lal (2012) had been also reported the similar findings.

Hence, application of $225 \mathrm{~kg}$ nitrogen, $135 \mathrm{~kg}$ $\mathrm{P}_{2} \mathrm{O}_{5}$ and $150 \mathrm{~kg} \mathrm{~K}_{2} \mathrm{O}$ per hectare may be adopted by the potato growers of north Bihar for medium duration potato cultivars.

\section{References}

Choudhary, B. Potato Handbook of Agriculture 1990. ICAR, New Delhi.

Kumar, P., Pandey, S. K., Singh, B.P., Rawal, S., Singh, S. V. And Kumar, D. Fertilizer requirement of chipping potato (Solanum tuberosum L.) cultivars in west-central plains, 2004. Potato Journal 31(3-4): 177-181.

Kumar, P., Trehan, S.P., Singh, B. P., Rawal, S., and Khan, M. A. Precision nitrogen requirement of table potato (Solanum tuberosum L.) cultivars for different growth periods. 2008. Indian Journal of Potato Association 28(1): 60-61.

Pandey, S.K., Kumar, P., Singh, B. P., Singh, S. V. And Kumar, D. Effect of nitrogen rate on growth, yield, economics and crisp quality of Indian potato processing cultivars. 2007. Potato Research 50(2): 143-155.

Patel, B. Effect of different levels of NPK on growth, development and yield of potato cv. Kufri Ashoka under Chattishgarh plain condition. M.Sc.(Ag) Thesis IGKV, Raipur. 2013. Pp 70-71.

Singh, K. P., Singh, R. K., Singh, S. N., and Singh, V. K. Effect of fertilizer level, seed rate and seed size on yield of potato in acidic soils of Manipur. Potato 
Journal. 2007. 34(1-2): 93-94.

Singh, S. K., and Lal, S. S. Effect of potassium nutrition on potato yield, quality and nutrient use efficiency under varied levels of nitrogen application. Potato Journal. 2012. 39(2): 155-165.

Sharma, K, A. and Kumar, V. Effect of varying levels of nitrogen and plant density on the production behaviour of under size seed tubers of potato (Solanum tuberosum L.) in northwestern hills of India. 2014. Indian Journal of Agricultural Sciences 84(3): 407-410.

\section{How to cite this article:}

Pankaj Kumar, D. K. Dwivedi, V. Bharati, Aman Tigga, H. Singh and Anshuman Dwivedi. 2021. Response of NPK on Growth and Yield of Potato (Solanum tuberosum L.) under Calcareous Soils of Bihar. Int.J.Curr.Microbiol.App.Sci. 10(02): 1956-1961. doi: https://doi.org/10.20546/ijcmas.2021.1002.234 